\title{
Synthesis of Novel Quinacridone Dyes and Their Photovoltaic Performances in Organic Dye-sensitized Solar Cells
}

\author{
Chun Sakong, Se Hun Kim, Sim Bum Yuk, Jeong Yun Kim, Se Woong Park, ${ }^{\dagger}$ Min Jae Ko, ${ }^{\dagger}$ and Jae Pil Kim* \\ Department of Materials Science and Engineering, Seoul National University, Seoul 151-744, Korea. *E-mail: jaepil@snu.ac.kr \\ 'Solar Cell Research Center, Materials Science and Technology Division, Korea Institute of Science and Technology (KIST), \\ Seoul 136-791, Korea \\ Received March 8, 2011, Accepted June 13, 2011
}

\begin{abstract}
Two novel quinacridone (QNC) dyes with thiophene or benzene-conjugated bridge and cyanoacrylic acid acceptor were first designed and synthesized for use in dye-sensitized solar cells (DSSCs). The absorption spectra, electrochemical and photovoltaic properties of these dyes were investigated. Under simulated AM $1.5 \mathrm{G}$ irradiation conditions, the solar cell based on the quinacridone dye containing thiophene as a bridge unit had a short-circuit photocurrent density of $8.51 \mathrm{~mA} \cdot \mathrm{cm}^{-2}$, an open-circuit voltage of $643.6 \mathrm{mV}$, and a fill factor of 0.70 , corresponding to an overall conversion efficiency of $3.86 \%$.
\end{abstract}

Key Words : Quinacridone chromophore, Organic dyes, Dye-sensitized solar cell, Intramolecular charge transfer, Thiophene, Benzene

\section{Introduction}

Dye-Sensitized Solar Cells (DSSCs) have attracted considerable attention in the field of renewable energy because of their easy processing, low production cost and high photoelectric conversion efficiency. ${ }^{1}$ The most typical dyes used in DSSCs are the ruthenium(II) polypyridyl complex series, which are known as N3 and N719. These Ru-complex dyes showed photoelectric conversion efficiencies over $11 \%{ }^{2}$ and good long-term stability. ${ }^{3}$ However, Ru-complex dyes have the disadvantage of high production cost and difficulties in purification. Recently, a variety of organic dyes have been developed as alternatives to Ru-complex dye. ${ }^{4}$ They have the advantages of low cost, ease of structural changes, ease of synthesis and high molar extinction coefficients.

In this study, we report the design and synthesis of new organic dyes containing linear trans-quinacridone chromophores (QNC). ${ }^{5}$ These chromophores have been studied for photovoltaic and photoconductive substances ${ }^{6,7}$ and have excellent durability as well as effective absorption in the 500-550 nm region. ${ }^{8}$ These new quinacridone dyes were composed of N-butylated quinacridone as a donor, a thiophene or benzene as a conjugated bridge and cyanoacrylic acid as the acceptor and anchoring group. In designing dyes, two butyl groups were introduced at the $\mathrm{N}$ atom of quinacridone to improve its solubility. ${ }^{7,9}$ In addition, a thiophene or benzene was introduced as a bridge unit to facilitate the synthesis because direct formylation employing Vilsmeier reagent $\left(\mathrm{POCl}_{3}\right)$ is difficult due to the carbonyl group included in quinacridone. ${ }^{10}$

\section{Experimental Section}

Materials and Methods. Quinacridone, 1-bromobutane, hexadecyltriammonium bromide and 4-formylphenyl boronic acid purchased from TCI, benzyltrimethylammonium tribromide, 5-formyl-2-thiophene boronic acid, tetrakis(triphenylphosphine)palladium(0), cyanoacetic acid and piperidine from Sigma-Aldrich were used without further purification. ${ }^{1} \mathrm{H}$ NMR spectra were recorded by Bruker Avance 500 at $500 \mathrm{MHz}$ using $\mathrm{CDCl}_{3}$ and $\mathrm{MeOD}$ as the solvent and TMS as the internal standard. Mass spectra were measured with JEOL JMS-600W Agilent 6890 Series. UV-Visible absorption spectra were measured with an HP 8452A spectrophotometer and emission spectra were recorded on a QuantaMaster $^{\mathrm{TM}}$ UV VIS spectrofluorometer. Cyclic voltammetry (CV) was performed with a three-electrode electrochemical cell on a Potentostat/Gavanostat Model 273A. Glassy-carbon, platinum wire, and $\mathrm{Ag} / \mathrm{Ag}+$ were employed as working, counter, and reference electrodes, respectively. Tetrabutylammonium tetrafluoroborate (TBATFB) was used as the supporting electrolyte and ferrocene was added as the internal reference for calibration.

Synthesis of Dyes.

5,12-Dibutylquinacridone (1): A suspension of quinacridone (1.56 g, $5 \mathrm{mmol}$ ), hexadecyltriammonium bromide (TBAB, $1.822 \mathrm{~g}, 5 \mathrm{mmol})$, toluene $(160 \mathrm{~mL})$ and $50 \%$ aqueous potassium hydroxide $(50 \mathrm{~g})$ was vigorously stirred and heated at $95{ }^{\circ} \mathrm{C}$. When quinacridone had completely dissolved, 1-bromobutane $(2.16 \mathrm{~mL}, 20 \mathrm{mmol})$ was added and the mixture was vigorously stirred for $24 \mathrm{hrs}$. And then the mixture was cooled to room temperature and poured slowly into ice water. The mixture was neutralized with $10 \% \mathrm{HCl}$ solution and the crude product was extracted with methylene chloride. The organic layer was washed with water and brine, dried over anhydrous $\mathrm{MgSO}_{4}$. The solvent was removed by rotary evaporation and subsequently dried in a vacuum oven. The crude product was purified by column chromatography on silica gel using methylene chloride. The yields, ${ }^{1} \mathrm{H}$ NMR 
and Mass data are given below.

Yield: 80\% (1.7 g). ${ }^{1} \mathrm{H}$ NMR $\left(\mathrm{CDCl}_{3}\right) \delta 8.78(\mathrm{~s}, 2 \mathrm{H}), 8.58$ $(\mathrm{d}, 2 \mathrm{H}), 7.77(\mathrm{t}, 2 \mathrm{H}), 7.52(\mathrm{~d}, 2 \mathrm{H}), 7.28(\mathrm{t}, 2 \mathrm{H}), 4.52(\mathrm{t}, 4 \mathrm{H})$, $2.01(\mathrm{~m}, 4 \mathrm{H}), 1.67(\mathrm{~m}, 4 \mathrm{H}), 1.12(\mathrm{~m}, 6 \mathrm{H})$. FAB MS: $m / z 425$ $[\mathrm{M}+]$. Anal. Calc. for $\mathrm{C}_{28} \mathrm{H}_{28} \mathrm{~N}_{2} \mathrm{O}_{2}$ : C, 79.22; H, 6.65; Found: C, $79.01 ; \mathrm{H}, 6.37$.

2-Bromo-5,12-dibutylquinacridone (2): 5,12-Dibutylquinacridone (1) (1.68 g, $3.5 \mathrm{mmol})$ was mixed with ethanol $(80 \mathrm{~mL})$ and benzyltrimethylammonium tribromide (BTA$\mathrm{TB}, 1.77 \mathrm{~g}, 4.5 \mathrm{mmol})$. The resulting mixture was stirred at ambient temperature for $24 \mathrm{hrs}$, and then heated at $85{ }^{\circ} \mathrm{C}$ for $20 \mathrm{hrs}$ to give limited reaction. Addition of chloroform (100 $\mathrm{mL}$ ) dissolved all solids and continued reflux gave moderate generation of mono- and di-brominated products. After evaporation of solvent, the product was purified by column chromatography on silica gel using methylene chloride.

Yield: $51 \%(0.88 \mathrm{~g}) .{ }^{1} \mathrm{H}$ NMR $\left(\mathrm{CDCl}_{3}\right) \delta 8.67(\mathrm{~s}, 1 \mathrm{H}), 8.63$ $(\mathrm{s}, 1 \mathrm{H}), 8.57(\mathrm{~s}, 1 \mathrm{H}), 8.49(\mathrm{~d}, 1 \mathrm{H}), 7.73-7.71(\mathrm{~m}, 2 \mathrm{H}), 7.46$ (d, 1H), 7.34 (d, 1H), $7.22(\mathrm{~m}, 1 \mathrm{H}), 4.46(\mathrm{~m}, 4 \mathrm{H})$ 1.97-1.93 (m, 4H), 1.3-1.11 (m, 6H). FAB MS: $m / z 503[\mathrm{M}+]$. Anal. Calc. for $\mathrm{C}_{28} \mathrm{H}_{27} \mathrm{BrN}_{2} \mathrm{O}_{2}$ : C, 66.80; H, 5.41; Found: C, 66.64; H, 5.21 .

5-(5,12-Dibutyl-7,14-dioxo-7,14-dihydro-12H-quino [2,3b]acridine-2-yl)thiophene-2-carbaldehyde (3a): 2-Bromo5,12-dibutylquinacridone (2) $(0.76 \mathrm{~g}, 1.5 \mathrm{mmol})$ was dissolved in a mixture $(7: 3)$ of dry toluene and ethanol $(75 \mathrm{~mL})$ and the solution was purged with argon gas for $10 \mathrm{~min}$. Tetrakis(triphenylphosphine)palladium $(0) \quad(0.086 \mathrm{~g}, \quad 0.075$ $\mathrm{mmol}$ ) was added followed by 5-formyl-2-thiophene boronic acid $(0.26 \mathrm{~g}, 1.66 \mathrm{mmol})$ and a $2 \mathrm{M}$ aqueous potassium carbonate solution $(3 \mathrm{~mL})$. The reaction mixture was heated at $110{ }^{\circ} \mathrm{C}$ for $12 \mathrm{hrs}$ and then cooled to room temperature. The organic solvents were evaporated under vacuum, and the residue was extracted with methylene chloride and water, washed with water and brine, and dried over anhydrous $\mathrm{MgSO}_{4}$. The solvent was removed by rotary evaporation and subsequently dried in a vacuum oven. The crude product was purified by column chromatography on silica gel using methylene chloride.

Yield: $35 \%(0.28 \mathrm{~g}) .{ }^{1} \mathrm{H}$ NMR $\left(\mathrm{CDCl}_{3}\right) \delta 9.92(\mathrm{~s}, 1 \mathrm{H}), 8.91$ $(\mathrm{s}, 1 \mathrm{H}), 8.83(\mathrm{~d}, 2 \mathrm{H}), 8.61(\mathrm{~d}, 1 \mathrm{H}), 8.06(\mathrm{~d}, 1 \mathrm{H}), 7.80(\mathrm{~d}, 2 \mathrm{H})$, $7.70(\mathrm{t}, 1 \mathrm{H}), 7.62(\mathrm{~d}, 1 \mathrm{H}), 7.55(\mathrm{~d}, 1 \mathrm{H}), 7.32(\mathrm{~m}, 1 \mathrm{H}), 4.57$ $(\mathrm{m}, 4 \mathrm{H}), 2.03(\mathrm{~m}, 4 \mathrm{H}), 1.68(\mathrm{~m}, 4 \mathrm{H}), 1.14(\mathrm{~m}, 6 \mathrm{H})$. FAB MS: $m / z 535[\mathrm{M}+]$. Anal. Calc. for $\mathrm{C}_{33} \mathrm{H}_{30} \mathrm{~N}_{2} \mathrm{O}_{3} \mathrm{~S}: \mathrm{C}, 74.13$; H, 5.66; Found: C, 73.95; H, 5.45 .

2-Cyano-3-(5-(5,12-dibutyl-7,14-dioxo-7,14-dihydro-12Hquino [2,3-b]acridine-2-yl)thiophene-2-yl) Cyanoacrylic Acid (QNC-1): A mixture of the carbaldehyde (3) $(0.27 \mathrm{~g}$, $0.5 \mathrm{mmol})$, cyannoacetic acid $(0.11 \mathrm{~g} 1.25 \mathrm{mmol})$ and piperidine $(0.15 \mathrm{~mL}, 1.5 \mathrm{mmol})$ was dissolved in acetonitrile $(150 \mathrm{~mL})$ and gently heated at $92{ }^{\circ} \mathrm{C}$ for $8 \mathrm{hrs}$ under nitrogen. After removal of solvent in vacuum, the crude product was purified by column chromatography on silica gel using chloroform/methanol $(5: 1, \mathrm{v} / \mathrm{v})$.

Yield: 54\% (0.162 g). ${ }^{1} \mathrm{H}$ NMR (MeOD) $\delta 8.55$ (s, 1H), $8.51(\mathrm{~d}, 2 \mathrm{H}), 8.28(\mathrm{~d}, 2 \mathrm{H}), 8.01(\mathrm{~d}, 1 \mathrm{H}), 7.89(\mathrm{~s}, 1 \mathrm{H}), 7.84(\mathrm{~d}$, 1H), $7.70(\mathrm{t}, 1 \mathrm{H}), 7.60(\mathrm{~m}, 2 \mathrm{H}), 7.49(\mathrm{~d}, 1 \mathrm{H}), 4.54(\mathrm{~m}, 4 \mathrm{H})$, $2.03(\mathrm{~m}, 4 \mathrm{H}), 1.68(\mathrm{~m}, 4 \mathrm{H}), 1.14(\mathrm{~m}, 6 \mathrm{H})$. FAB MS: $m / z 602$ $[\mathrm{M}+]$. Anal. Calc. for $\mathrm{C}_{36} \mathrm{H}_{31} \mathrm{~N}_{3} \mathrm{O}_{4} \mathrm{~S}$ : C, 71.86; H, 5.19; Found: C, 71.68; H, 4.98.

Compound 3b: This compound was prepared using the method established for 3a.

Yield: $42 \%(0.31 \mathrm{~g}) .{ }^{1} \mathrm{H}$ NMR $\left(\mathrm{CDCl}_{3}\right) \delta 10.08(\mathrm{~s}, 1 \mathrm{H})$, $8.87(\mathrm{~s}, 1 \mathrm{H}), 8.79(\mathrm{~d}, 2 \mathrm{H}), 8.57(\mathrm{~d}, 1 \mathrm{H}), 8.05(\mathrm{~d}, 1 \mathrm{H}), 8.01(\mathrm{~d}$, $2 \mathrm{H}), 7.90(\mathrm{~d}, 2 \mathrm{H}), 7.75(\mathrm{t}, 1 \mathrm{H}), 7.64(\mathrm{~d}, 1 \mathrm{H}), 7.53(\mathrm{~d}, 1 \mathrm{H})$, $7.29(\mathrm{~m}, 1 \mathrm{H}), 4.57(\mathrm{~m}, 4 \mathrm{H}), 2.03(\mathrm{~m}, 4 \mathrm{H}), 1.68(\mathrm{~m}, 4 \mathrm{H}), 1.14$ (m, 6H). FAB MS: $m / z 529[\mathrm{M}+]$. Anal. Calc. for $\mathrm{C}_{35} \mathrm{H}_{32} \mathrm{~N}_{2} \mathrm{O}_{3}$ : C, 79.52; H, 6.10; Found: C, 79.34; H, 5.87.

QNC-2: This compound was prepared using the method established for QNC-1.

Yield: $56 \%(0.165 \mathrm{~g}) .{ }^{1} \mathrm{H}$ NMR $\left(\mathrm{CDCl}_{3}\right) \delta 8.65(\mathrm{~s}, 2 \mathrm{H})$, $8.64(\mathrm{~d}, 1 \mathrm{H}), 8.35(\mathrm{~d}, 1 \mathrm{H}), 8.23(\mathrm{~d}, 1 \mathrm{H}), 8.01(\mathrm{~d}, 2 \mathrm{H}), 7.97$ $(\mathrm{d}, 1 \mathrm{H}), 7.96(\mathrm{t}, 1 \mathrm{H}), 7.90(\mathrm{~d}, 2 \mathrm{H}), 7.84(\mathrm{~d}, 2 \mathrm{H}), 7.30(\mathrm{~s}, 1 \mathrm{H})$, $4.59(\mathrm{~m}, 4 \mathrm{H}), 1.89(\mathrm{~m}, 4 \mathrm{H}), 1.62(\mathrm{~m}, 4 \mathrm{H}), 1.08(\mathrm{~m}, 6 \mathrm{H})$. FAB MS: $m / z 596[\mathrm{M}+]$. Anal. Calc. for $\mathrm{C}_{38} \mathrm{H}_{33} \mathrm{~N}_{3} \mathrm{O}_{4}$ : C, 76.62; H, 5.58; Found: C, 76.43; H, 5.46.

Fabrication of Solar Cells and Photovoltaic Measurement: FTO glass plates (Pilkington, TEC-8, $8 \Omega$ /square, 2.3 $\mathrm{mm}$ thick) were cleaned with ethanol by ultrasonication for $10 \mathrm{~min}$, and then treated in a $\mathrm{UV}-\mathrm{O}_{3}$ system for $20 \mathrm{~min}$. The FTO layer was first covered with 7.5\% Ti(IV) bis(ethyl acetoacetato)-diisopropoxide solution by spin-coating method. For the transparent nanocrystalline layer, $\mathrm{TiO}_{2}$ paste (230(M2331)-2T) was coated on the FTO glass plates by doctor blade printing, and then sintering was carried out at $500{ }^{\circ} \mathrm{C}$ for $30 \mathrm{~min}$. $\mathrm{TiO}_{2}$ paste (CCIC-1T) for the scattering layer was prepared using the same method. The resulting layer was composed of $9 \mu \mathrm{m}$ thickness of transparent layer and $4 \mu \mathrm{m}$ thickness of scattering layer. Active area of $\mathrm{TiO}_{2}$ films was about $0.23 \mathrm{~cm}^{2}$. The $\mathrm{TiO}_{2}$ electrodes were immersed into the dye solution $(0.5 \mathrm{mM}$ in chloroform-methanol (1:1) solution) and kept at room temperature for $40 \mathrm{hrs}$. Counter electrodes were prepared by droping a $0.7 \mathrm{mM}$ $\mathrm{H}_{2} \mathrm{PTCl}_{6}$ solution on a FTO glasses and heating at $400{ }^{\circ} \mathrm{C}$ for 20 min. The dye-absorbed $\mathrm{TiO}_{2}$ electrode and the counter electrode were sealed using $25 \mu \mathrm{m}$-thick surlyn film (Dupont 1702). An electrolyte solution was introduced through a drilled hole on the counter electrode, where the electrolyte solution was consisted of $0.5 \mathrm{M} 1$-methyl-3-propylimidazolium iodide (PMII), 0.2 M LiI, 0.05 $\mathrm{M} \mathrm{I}_{2}$, and 0.5 M 4tert-butylpyridine (TBP) in ACN/VN (85:15). Photovoltaic measurements were performed using a Keithly model 2400 source measuring unit. A $1000 \mathrm{~W}$ Xe lamp (Spectra-physics) served as a light source and its light intensity was adjusted using a NREL-calibrated silicon solar cell equipped with a KG-5 filter to approximate AM 1.5G of sun light intensity. IPCE was measured as a function of wavelength from 300$800 \mathrm{~nm}$ using a specially designed IPCE system for dyesensitized solar cells (PV Measurements, Inc.). A 75W Xe lamp was used as the light source for generation of a monochromatic beam. Calibrations were performed using a silicon photodiode, which was calibrated using NIST-calibrated photodiode G425 as a standard, and IPCE values were collected at a low chopping speed of $10 \mathrm{~Hz}$. 


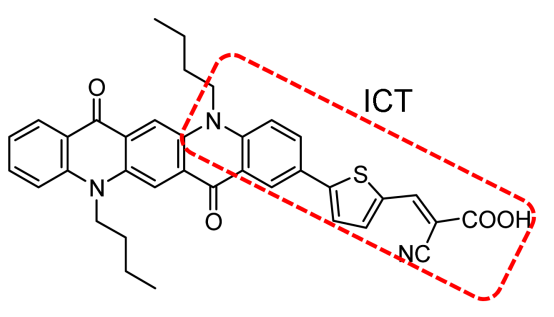

QNC-1<smiles></smiles>

QNC-2

Figure 1. Molecular structures of QNC-1 and QNC-2.

\section{Results and Discussion}

Synthesis of Dyes. Molecular structures of the synthesized dyes are as shown in Figure 1 and their synthetic routes are illustrated in Scheme 1. Firstly, $N$-butylation of quinacridone $^{9}$ was carried out to improve its solubility in organic solvents such as dichloromethane, chloroform, toluene, ethyl acetate, etc. Secondly, the quinacridone was brominated at the 2-position with BTA-TB (benzyltrimethylammonium tribromide) for the synthesis of asymmetric quinacridone. ${ }^{11}$ A mono-brominated quinacridone was coupled with 5-formyl-2-thiophene boronic acid or 4-formylphenyl boronic acid under Suzuki coupling conditions ${ }^{12}$ and finally condensed with cyanoacrylic acid.

Optical Properties of QNC Dyes in Solution and $\mathbf{T i O}_{2}$ Film. Figure 2(a) shows the UV-Visible absorption spectra of intermediate 1, QNC-1 and QNC-2, and their optical properties are collected in Table 1. The spectrum of the intermediate 1 shows single absorption band corresponding to a localized aromatic $\pi-\pi^{*}$ transition at $530 \mathrm{~nm}$. As shown in Figure 1, QNC-1 and QNC-2 exhibit two prominent absorption bands at $414 \mathrm{~nm} / 538 \mathrm{~nm}$ and $384 \mathrm{~nm} / 536 \mathrm{~nm}$, respectively. The absorption bands at the longer wavelength are due to the localized aromatic $\pi-\pi^{*}$ transition and redshifted from that of intermediate 1 only $6-8 \mathrm{~nm}$ when a bridge and an anchoring group were introduced. On the other hand, the strong absorption bands at the shorter wavelength red-shifted considerably, approximately $74 \mathrm{~nm}$ and $44 \mathrm{~nm}$. Moreover, the molar extinction coefficients of the dyes at these wavelengths also increased dramatically compared to that of the localized aromatic $\pi-\pi^{*}$ transition. It is well known that the introduction of electron-withdrawing groups or an expansion of the conjugation length in dye structure generally produces intramolecular charge transfer (ICT) between the donor part of the molecule and the acceptor group with a strong red-shifted absorption band and increased intensity. ${ }^{13}$ Therefore, the strong absorption band at the shorter wavelength can be assigned to the intramolecular charge transfer band. This assignment is also supported by solvatochromic behavior of the dyes. As shown in Figure 2(b), the aromatic $\pi-\pi^{*}$ transition band at $538 \mathrm{~nm}$ are nearly solvent polarity independent, whereas the intramolecular charge transfer band at $414 \mathrm{~nm}$ exhibits negative solvatochromism, i.e., blue shift of $\lambda_{\max }$ in more polar solvents. In general, the intramolecular charge transfer band of organic dye with $D-\pi$-A structure appears at longer wavelength than

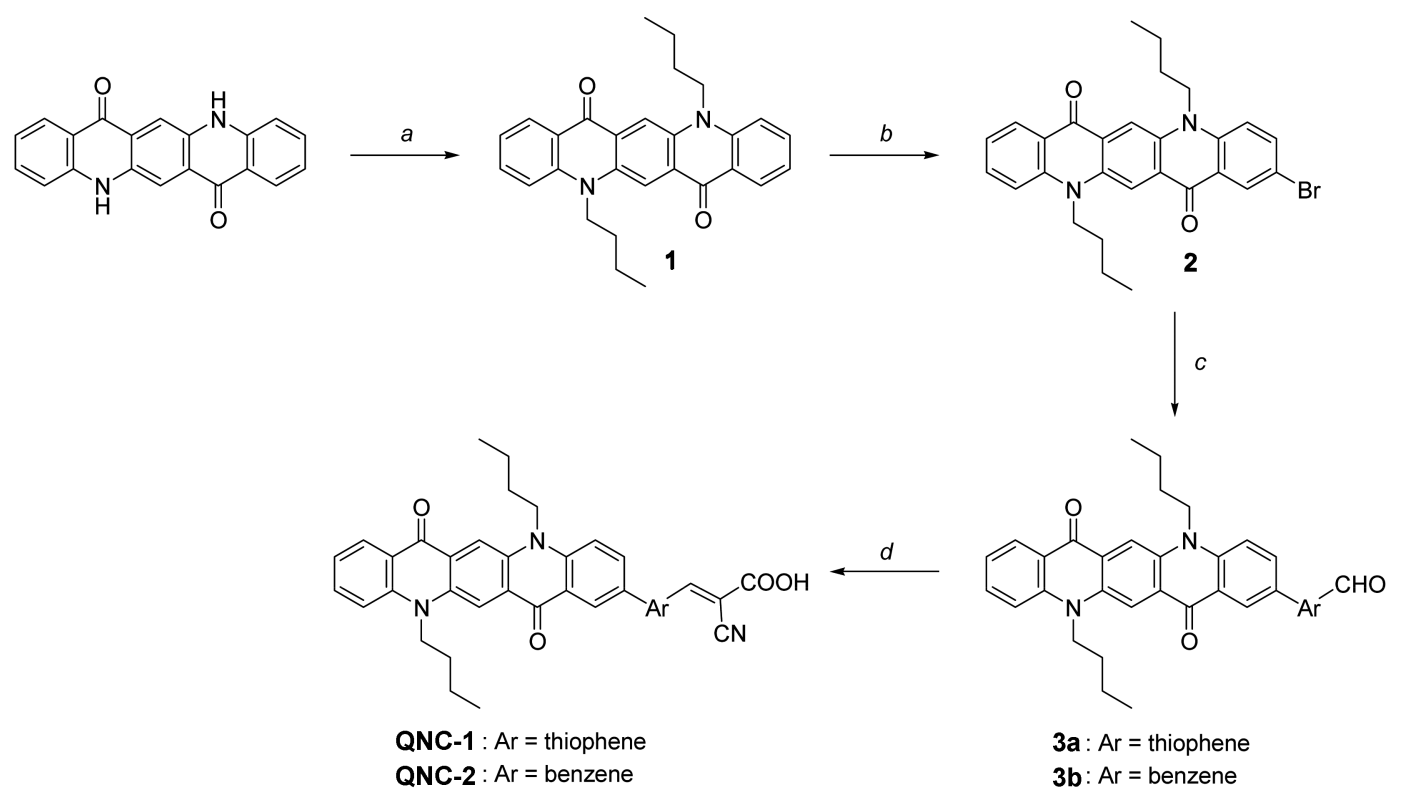

Scheme 1. Synthetic routes for the synthesis of QNC dyes; (a) 1-bromobutane, hexadecyltriammonium bromide, $\mathrm{KOH}$, reflux in toluene (b) benzyltrimethylammonium tribromide, ethanol, room temp. $\rightarrow$ reflux $(c)$ 5-formyl-2-thiophene boronic acid or 4-formylphenyl boronic acid, tetrakis(triphenylphosphine)palladium(0), toluene:ethanol (7:3), reflux (d) cyannoacetic acid, piperidine, reflux in acetonitrile. 

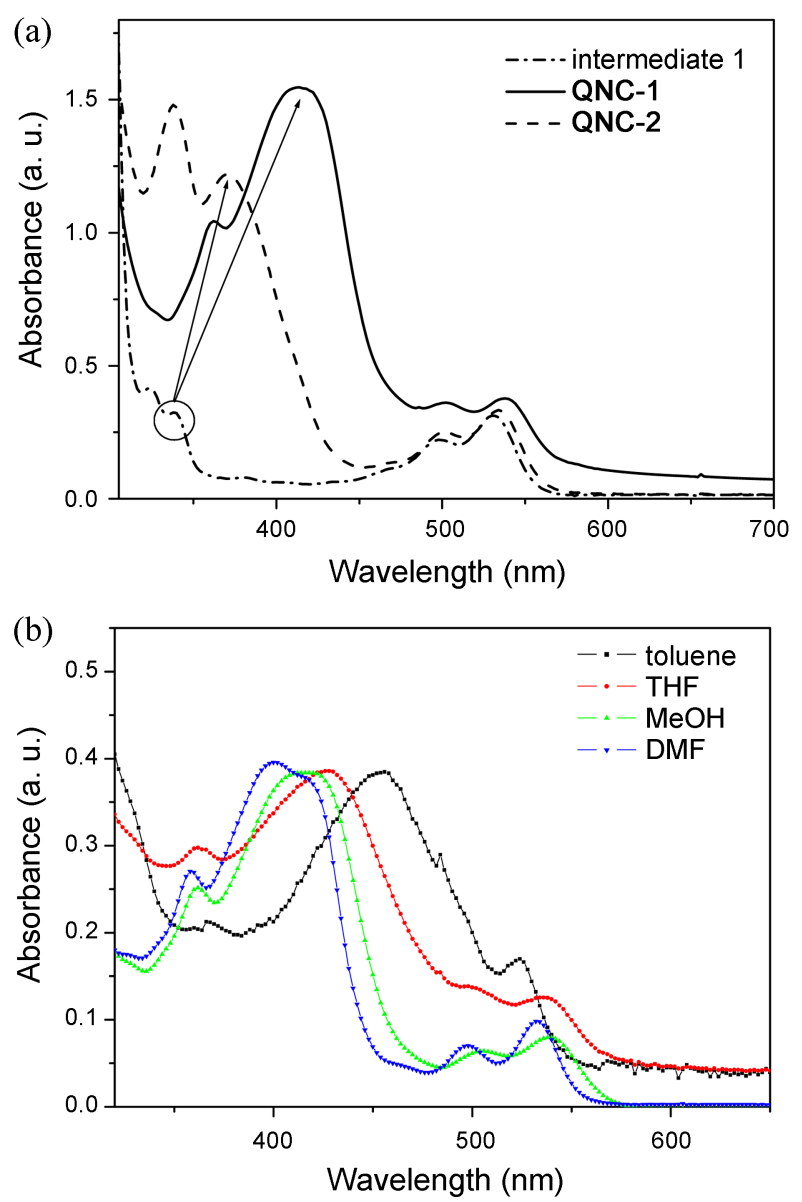

Figure 2. Absorption spectra of intermediate 1, QNC-1 and QNC2 in methanol (a) and absorption spectra of QNC-1 in different solvents (b).

Table 1. Optical and electrochemical properties of QNC-1 and QNC-2

\begin{tabular}{cccccc}
\hline \multirow{2}{*}{ Dye } & $\begin{array}{c}\lambda_{\max }{ }^{a} / \mathrm{nm} \\
\left(\varepsilon / \mathrm{M}^{-1} \mathrm{~cm}^{-1}\right)\end{array}$ & $\begin{array}{c}\lambda_{\max } \text { on } \\
\mathrm{TiO}_{2} / \mathrm{nm}\end{array}$ & \multicolumn{3}{c}{ Potentials and energy levels } \\
\cline { 5 - 6 } & & $\mathrm{E}_{\mathrm{ox}}{ }^{b} / \mathrm{V}$ & $\mathrm{E}_{0-0}{ }^{c} / \mathrm{V}$ & $\mathrm{E}_{\mathrm{ox}}-\mathrm{E}_{0-0} / \mathrm{V}$ \\
\hline QNC-1 & $414(45,200)$ & 426 & 1.14 & 2.17 & -1.03 \\
& $538(15,100)$ & & & & \\
QNC-2 & $384(38,500)$ & 414 & 1.21 & 2.21 & -1.00 \\
\hline
\end{tabular}

${ }^{a}$ Absorption maxima in methanol solution. ${ }^{b}$ The oxidation potentials $\left(\mathrm{E}_{\mathrm{Ox}}\right)$ of the dyes were obtained by cyclic voltammetry in $\mathrm{CH}_{2} \mathrm{Cl}_{2}$ with $0.1 \mathrm{M}$ tetrabutylammonium tetrafluoroborate (TBATFB) with a scan rate of $100 \mathrm{mV} \cdot \mathrm{s}^{-1}$ and converted to NHE. ${ }^{c} \mathrm{E}_{0-0}$ of dyes were estimated from the edge of absorption spectra.

the localized $\pi-\pi^{*}$ transition band. But, in case of QNC dyes, the intramolecular charge transfer band appeared at shorter wavelength than the localized $\pi-\pi^{*}$ transition band. It is considered that only the benzene ring containing $N$-butyl group in quinacridone is included in conjugation with anchoring group, resulting in shorter conjugation path for intramolecular charge transfer with shorter absorption wavelength compared with the localized $\pi-\pi^{*}$ transition band.

QNC-1 bearing thiophene as the conjugated bridge showed a larger and stronger red-shift in the intramolecular charge transfer band compared to QNC-2. This is consider-

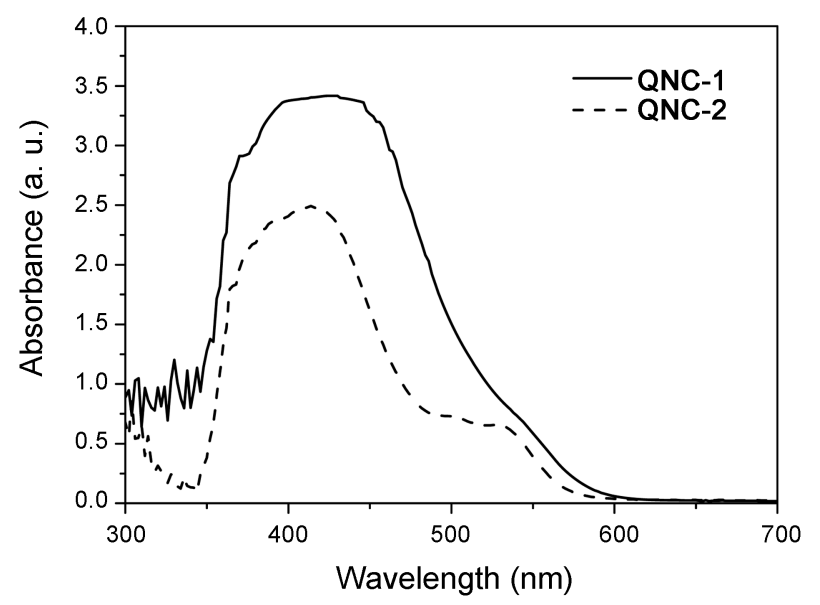

Figure 3. Absorption spectra of QNC-1 and QNC-2 adsorbed on $\mathrm{TiO}_{2}$.

ed due to the different resonance stabilization energy of bridge unit and coplanarity of dye molecule. It has been known that a thiophene has a lower energy of charge transfer transition ${ }^{14}$ because of its smaller resonance stabilization energy (thiophene, $29 \mathrm{Kcal} / \mathrm{mol}$; benzene, $36 \mathrm{Kcal} / \mathrm{mol}$ ) compared with a benzene. ${ }^{15}$ Also, the thiophene can provide more effective conjugation due to its better coplanarity with quinacridone donor. As shown in Figure 7(a), the dihedral angles between quinacridone donor and bridge unit for QNC-1 and QNC-2 are $19.8^{\circ}$ and 33.6 ${ }^{\circ}$, respectively. This red-shift in the absorption spectrum could improve the amount of light harvested and enhance the photocurrent generation of DSSCs.

Figure 3 shows the absorption spectra of QNC-1 and QNC-2 on $\mathrm{TiO}_{2}$ films. As shown in Figure 3, the absorption maxima of intramolecular charge transfer bands for QNC-1 and QNC-2 on the $\mathrm{TiO}_{2}$ films were at $426 \mathrm{~nm}$ and $414 \mathrm{~nm}$, which red-shifted by $12 \mathrm{~nm}$ and $30 \mathrm{~nm}$ compared with those in methanol, respectively. ${ }^{16}$ The $\pi-\pi^{*}$ transition bands of the dyes weakly appeared around 500-550 nm.

Electrochemical Properties of QNC Dyes. The oxidation potential $\left(\mathrm{E}_{\mathrm{ox}}\right)$ corresponding to the HOMO level of the dye

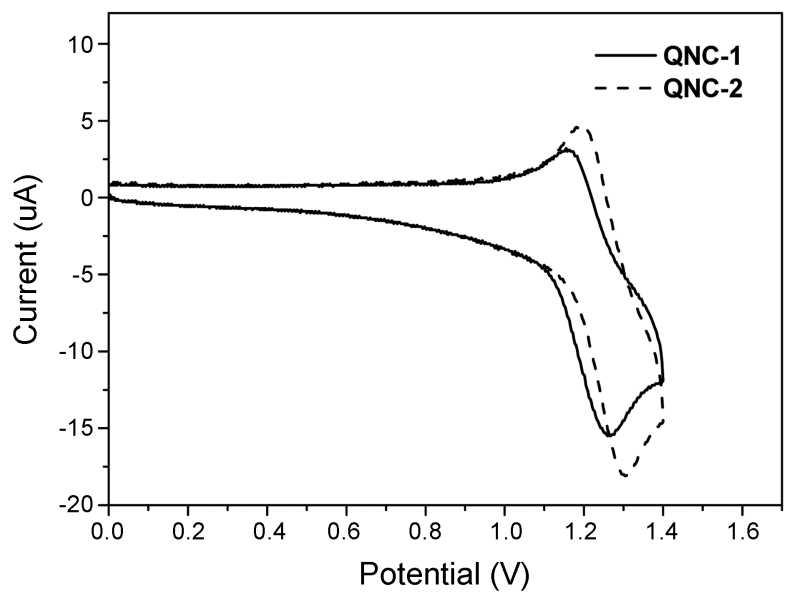

Figure 4. Cyclic voltammograms of QNC-1 and QNC-2. 
Table 2. Photovoltaic properties of QNC-1 and QNC-2

\begin{tabular}{ccccc}
\hline \multirow{2}{*}{ Dye } & \multicolumn{4}{c}{ Photovoltaic performance data $^{a}$} \\
\cline { 2 - 5 } & $\mathrm{J}_{\mathrm{sc}} / \mathrm{mA} \cdot \mathrm{cm}^{-2}$ & $\mathrm{~V}_{\mathrm{oc}} / \mathrm{mV}$ & $\mathrm{FF}$ & $\eta(\%)$ \\
\hline QNC-1 & 8.51 & 643.6 & 0.70 & 3.86 \\
QNC-2 & 5.29 & 629.1 & 0.69 & 2.30 \\
\hline
\end{tabular}

${ }^{a}$ The concentration was maintained at $5 \times 10^{-4} \mathrm{M}$ in chloroform-methanol (1:1) solution, with $0.5 \mathrm{M}$ 1-methyl-3-propylimidazolium iodide (PMII), 0.2 M LiI, $0.05 \mathrm{M} \mathrm{I}_{2}$ and $0.5 \mathrm{M}$ 4-tert-butylpyridine (TBP) in ACN-VN (85:15) solution. Performance of DSSC was measured with a $0.23 \mathrm{~cm}^{2}$ working area.

was obtained from cyclic voltammetry (CV) and the LUMO level was calculated by $\mathrm{E}_{0 x}-\mathrm{E}_{0-0}$. The $\mathrm{E}_{0-0}$ is the zerothzeroth energy of the dye determined from the inflection point at the end of the visible absorption spectrum of the dye. ${ }^{17}$ The cyclic voltammograms of the synthesized dyes are shown in Figure 4 and corresponding data are collected in Table 1. The oxidation potentials of QNC-1 and QNC-2 were $1.14 \mathrm{eV}$ and $1.21 \mathrm{eV}$, respectively, which are more positive than the redox potential of the electrolyte $(0.4 \mathrm{eV} v s$ NHE). The LUMO levels of QNC-1 and QNC-2 were -1.03 $\mathrm{eV}$ and $-1.00 \mathrm{eV}$, respectively, which are more negative than the conduction band of $\mathrm{TiO}_{2}(-0.5 \mathrm{eV} v s \mathrm{NHE}) .{ }^{18}$ Therefore, the HOMO-LUMO levels of the synthesized dyes were suitable for DSSCs to be driven.

Photovoltaic Properties of DSSCs. DSSCs were fabricated using the synthesized dyes according to the methods described in the Experimental section. The photovoltaic performances of these DSSCs are listed in Table 2, and the respective photocurrent density-voltage $(\mathrm{J}-\mathrm{V})$ curves are shown in Figure 5. Under standard AM 1.5 G irradiation, the maximum efficiency $(\eta)$ for the QNC-1-sensitized solar cell with an active area of $0.23 \mathrm{~cm}^{2}$ was calculated to be $3.86 \%$, with a short-circuit current $\left(\mathrm{J}_{\mathrm{sc}}\right)$ of $8.51 \mathrm{~mA} \cdot \mathrm{cm}^{-2}$, an opencircuit voltage $\left(\mathrm{V}_{\mathrm{oc}}\right)$ of $643.6 \mathrm{mV}$ and a fill factor (ff) of 0.70 . On the other hand, the DSSCs based on QNC-2 showed a relatively lower $\mathrm{J}_{\mathrm{sc}}$, leading to a lower $\eta$ value of $2.3 \%$. This was attributed to the more red-shifted and broader absorption spectrum of QNC-1 bearing a thiophene as a conjugated

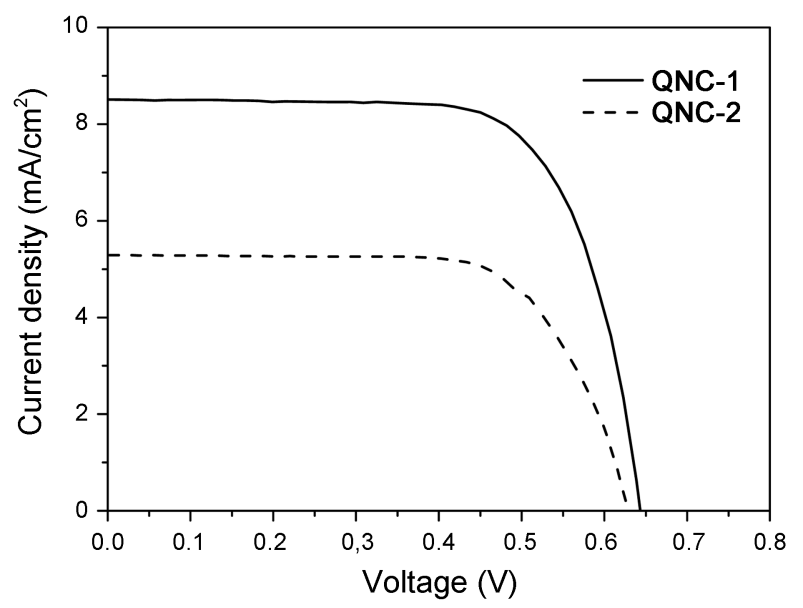

Figure 5. Photocurrent-voltage curves for the DSSCs based on QNC-1 and QNC-2 under AM 1.5 G simulated solar light (100 $\left.\mathrm{mW} \cdot \mathrm{cm}^{-2}\right)$.

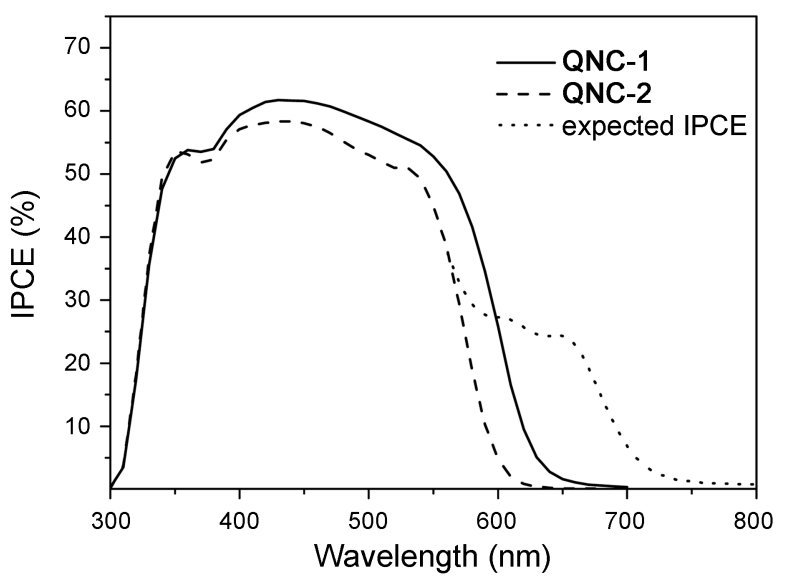

Figure 6. Incident photon-to-current conversion efficiencies spectra for the DSSCs based on QNC-1 and QNC-2.

bridge than that of QNC-2 bearing a benzene.

Figure 6 shows the incident monochromatic photon-tocurrent conversion efficiencies (IPCE) of the DSSCs based on the QNC dyes. The range of the IPCE spectrum based on QNC-1 was up to $670 \mathrm{~nm}$ with the highest value of $61.74 \%$ at $430 \mathrm{~nm}$. On the other hand, the range of the IPCE spectrum based on QNC-2 was up to $625 \mathrm{~nm}$, and it exhibited a lower IPCE with a maximum of $58.33 \%$ at $430 \mathrm{~nm}$. The rather low IPCE value for QNC-2 indicates a lower photocurrent and inferior photovoltaic performance.

The IPCE spectrum generally reflects the corresponding absorption spectrum of a dye on $\mathrm{TiO}_{2}$ film and its onset usually expands approximately $200 \mathrm{~nm}$ compared to that of the absorption spectrum of the dye. ${ }^{19}$ However, in the case of QNC dyes, the IPCE spectra didn't correspond with the absorption spectra of the dyes on $\mathrm{TiO}_{2}$ films and did not fully red-shifted as expected. The absorption bands at shorter wavelength $(426 \mathrm{~nm}$ and $414 \mathrm{~nm})$ of the QNC dyes were reflected in the IPCE spectra, but those of the longer wavelength above $500 \mathrm{~nm}$ were not. If the absorption bands at a longer wavelength were used to generate the photocurrent, the onset of the IPCE spectrum should have been expanded up to $750 \mathrm{~nm}$. This means that only absorption bands due to the intramolecular charge transfer, occurring between the $N$-butyl group at the quinacridone donor and cyanoacrylic acid acceptor, contributed to the monochromatic incident photon-to-current conversion efficiency. We postulate that the two carbonyl groups on quinacridone framework with intense electron-withdrawing property compete with cyanoacrylic acid anchoring group and prevent the transfer of localized electrons in the quinacridone moiety resulting no contribution of longer absorption wavelength to IPCE.

Computational Study. All calculations were done by the Gaussian 09 program. The molecular geometry and the electron distributions of the synthesized dyes for the HOMO and LUMO state were calculated with DFT on a B3LYP/6$31+G(d)$ level. The electron densities in the HOMO states were higher at $N$-butyl groups on quinacridone framework, but they effectively shifted toward the anchoring group in 
(a)
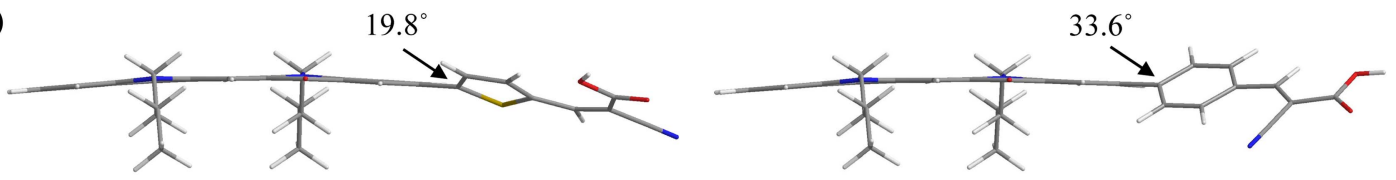

(b)
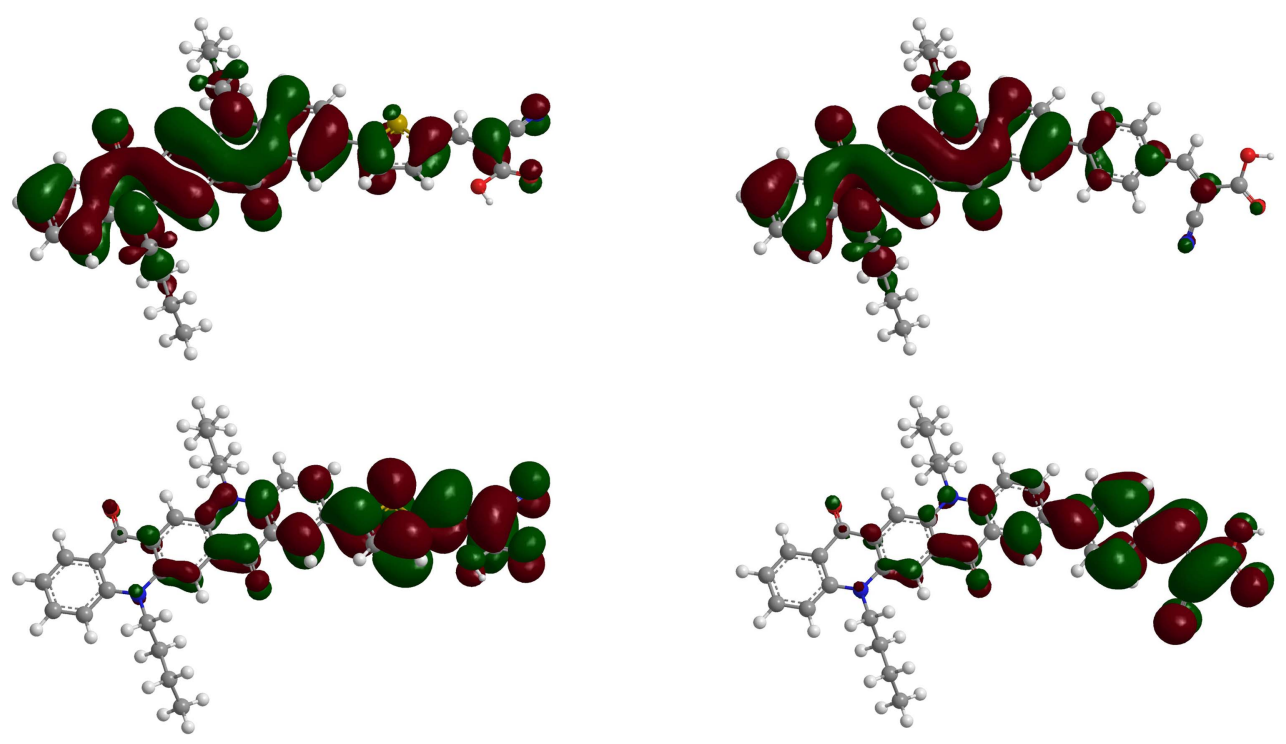

QNC-1

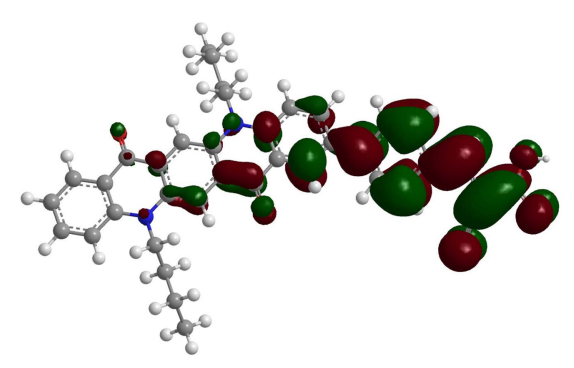

QNC-2

Figure 7. Optimized molecular geometry (a) and frontier molecular orbitals of the HOMO and LUMO (b) calculated with DFT on a B3LYP/6-31+G(d) level of QNC dyes.

the LUMO states. It is considered that the electron transfer from $N$-butyl group on the quinacridone framework to the anchoring group easily occurred by introduction of cyanoacrylic acid group as a stronger acceptor and anchoring group. As a result, the quinacridone dyes have superior photovoltaic performances compared to those of anthraquinone ${ }^{20}$ and perylene dyes, ${ }^{21}$ although they have two carbonyl groups with the strong electron-withdrawing character on framework.

\section{Conclusion}

We have first designed and synthesized two novel quinacridone dyes with thiophene or benzene-conjugated bridge and cyanoacrylic acid acceptor and applied them to DSSCs. The intramolecular charge transfer bands of QNC dyes appeared at shorter wavelength than the localized $\pi-\pi^{*}$ transition bands due to shorter conjugation path (from $N$ butyl to anchoring group) for intramolecular charge transfer. The photovoltaic measurements showed that two quinacridone dyes had rather low overall conversion efficiency, which was $3.86 \%$ and $2.3 \%$, respectively. We found that such lower conversion efficiency is due to the two carbonyl groups on quinacridone framework with intense electronwithdrawing property, which compete with cyanoacrylic acid anchoring group and prevent the transfer of localized electrons in the quinacridone moiety resulting contribution of only shorter absorption wavelength to IPCE. Although quinacridone dyes have good durability and high molar extinction coefficients, further structural modification to move the residual electrons from the quinacridone moiety to the anchoring group is needed to improve their performance in DSSCs.

Acknowledgments. This work was supported by the Korea Evaluation Institute of Industrial Technology grant funded by the Korea government (MKE).

\section{References}

1. (a) O'Regan, B.; Grätzel, M. Nature 1991, 353, 737. (b) Grätzel, M. Nature 2001, 414, 338.

2. (a) Chiba, Y.; Islam, A.; Watanabe, Y.; Komiya, R.; Koide, N.; Han, L. Jpn. J. Appl. Phys. 2006, 45, L638. (b) Nazeeruddin, M. K.; Angelis, F. D.; Fantacci, S.; Selloni, A.; Viscardi, G.; Liska, P.; Ito, S.; Takeru, B.; Grätzel, M. J. Am. Chem. Soc. 2005, 127, 16835. (c) Wang, Z.-S.; Yamaguchi, T; Sugihara, H.; Arakawa, H. Langmuir 2005, 21, 4272.

3. Wang, P.; Zakeeruddin, S. M.; Moser, J. E.; Nazeeruddin, M. K.; Sekiguchi, T.; Grätzel, M. Nat. Mater. 2003, 2, 402.

4. Mishra, A.; Fischer, M. K.; Bäuerle, P. Angew. Chem., Int. Ed. 2009, 48, 2474.

5. (a) Labana, S. S.; Lababa, L. L. Chem. Rew. 1967, 67, 1. (b) Herbst, W.; Hunger, K. Industrial Pigments; VCH: Weinheim, 1993; 447. (c) Lincke, G. Dyes and Pigments 2002, 52, 169.

6. (a) Manabe, K.; Kusabayashi, S.; Yokoyama, M. Chem. Lett. 1987, 609. (b) Marco, P. D.; Fattori, V.; Giro, G.; Kalinowski, J. Mol. Cryst. Liq. Cryst. 1992, 217, 223. (c) Tsutsui, T.; Aminaka, E.; Fujita, Y.; Hamada, Y.; Saito, S. Synth. Met. 1993, 57, 4157. 
(d) Shi, J.; Tang, C. W. Appl. Phys. Lett. 1997, 70, 1665. (e) Jabbour, G. E.; Kawabe, Y.; Shaheen, S. E.; Wang, J. F.; Morrell, M. M.; Kippelen, B.; Peyghambarian, N. Appl. Phys. Lett. 1997, 71, 1762. (f) Feyter, S. D.; Gesquière, A.; Schryver, F. C. D.; Keller, U.; Müllen, K. Chem. Mater. 2002, 14, 989. (g) Mu, Z.; Wang, Z.; Zhang, X.; Ye, K.; Wang, Y. J. Phys. Chem. B 2004, 108, 19955. (h) Yang, X.; Mu, Z.; Wang, Z.; Zhang, X.; Wang, J.; Wang, Y. Langmuir 2005, 20, 7225.

7. (a) Ortiz, A.; Flora, W. H.; D'Ambruoso, G. D.; Armstrong, N. R.; McGrath, D. V. Chem. Commun. 2005, 444. (b) Liu, J.; Gao, B.; Cheng, Y.; Xie, Z.; Geng, Y.; Wang, L.; Jing, X.; Wang, F. Macromolecules 2008, 41, 1162.

8. Sakong, C.; Kim, Y. D.; Choi, J.-H.; Yoon, C.; Kim, J. P. Dyes and Pigments 2011, 88, 166.

9. (a) Liu, P. H.; Tian, H.; Chang, C. P. J. Photochem. Photobiol. A 2000, 137, 99. (b) Smith, J. A.; West, R. M.; Allen, M. J. Fluoresc. 2004, 14, 151.

10. Marson, C. M. Tetrahedron 1992, 48, 3659.

11. Smith, J. A. inventor; GE Healthcare UK Limited, assignee. United States Patent US 7335771. 2008 Feb 26.

12. Pomel, V.; Klicic, J.; Covini, D.; Church, D. D.; Shaw, J. P.; Roulin, K.; Burgat-Charvilon, F.; Valognes, D.; Camps, M.; Chabert, C.; Gillieron, C.; Francon, B.; Perrin, D.; Leroy, D.; Gretener, D.; Nichols, A.; Vitte, P. A.; Carboni, S.; Rommel, C.; Schwarz, M. K.; Rückle, T. J. Med. Chem. 2006, 49, 3857.

13. (a) Roquet, S.; Cravino, A.; Leriche, P.; Alévêque, O.; Frère, P.; Roncali, J. J. Am. Chem. Soc. 2006, 128, 3459. (b) Thomas, K. R. J.; Hsu, Y. C.; Lin, J. T.; Lee, K. M.; Ho, K. C.; Lai, C. H.; Cheng, Y. M.; Chou, P. T. Chem. Mater. 2008, 20, 1830.

14. (a) Morley, J. O.; Push, D. J. Chem. Soc. Faraday Trans. 1991, 87, 3021. (b) Wu, I. Y.; Lin, J. T.; Li, C. S.; Tsai, C.; Wen, Y. S.; Hsu,
C. C.; Yeh, F. F.; Liou, S. Organometallics 1998, 17, 2188.

15. March, J. Advanced Organic Chemistry, 4th ed.; Wiley: New York, U.S.A., 1992; p 45.

16. (a) Ramakishna, G.; Ghosh, H. N. J. Phys. Chem. A 2002, 106 , 2545. (b) Wu, W.; Yang, J.; Hua, J.; Tang, J.; Zhang, L.; Long, Y.; Tian, H. J. Mater. Chem. 2010, 20, 1772.

17. Hwang, S.; Lee, J. H.; Park, C.; Lee, H.; Kim, C.; Park, C.; Lee, M. H.; Lee, W.; Park, J.; Kim, K.; Park, N. G.; Kim, C. Chem. Commun. 2007, 4887.

18. (a) Hara, K.; Tachibana, Y.; Ohga, Y.; Shinpo, A.; Sugab, S.; Sayamaa, K.; Sugihara, H.; Arakawa, H. Sol. Energy Mater. Sol. Cells 2003, 77, 89. (b) Hara, K.; Sato, T.; Katoh, R.; Furube, A.; Ohga, Y.; Shinpo, A.; Suga, S.; Sayama, K.; Sugihara, H.; Arakawa, H. J. Phys. Chem. B 2003, 107, 597. (c) Kuang, D.; Walter, P.; Nüesch, F.; Kim, S.; Ko, J.; Comte, P.; Zakeeruddin, S. M.; Nazeeruddin, M. K.; Grätzel, M. Langmuir 2007, 23, 10906. (d) Hagberg, D. P.; Marinado, T.; Karlsson, K. M.; Nonomura, K.; Qin, P.; Boschloo, G.; Brinck, T.; Hagfeldt, A.; Sun, L. J. Org. Chem. 2007, 72, 9550.

19. Tae, E. L.; Lee, S. H.; Lee, J. K.; Yoo, S. S.; Kang, E. J.; Yoon, K. B. J. Phys. Chem. B 2005, 109, 22513.

20. Li, C.; Yang, X.; Chen, R.; Pan, J.; Tian, H.; Zhu, H.; Wang, X.; Hagfeldt, A.; Sun, L. Sol. Energy Mater. Sol. Cells 2007, 91, 1863.

21. (a) Ferrere, S.; Zaban, A.; Gregg, B. A. J. Phys. Chem. B 1997, 101, 4490. (b) Ferrere, S.; Gregg, B. A. J. Phys. Chem. B 2001, 105, 7602. (c) Ferrere, S.; Gregg, B. A. New J. Chem. 2002, 26, 1155. (d) Shibano, Y.; Umecyama, T.; Matano, Y.; Imahori, H. Org. Lett. 2007, 9, 1971. (e) Fortage, J.; Séverac, M.; HouarnerRassin, C.; Pellegrin, Y.; Blart, E.; Odobel, F. J. Photochem. Photobiol. A 2008, 197, 156. (f) Jin, Y.; Hua, J.; Wu, W.; Ma, X.; Meng, F. Synth. Met. 2008, 158, 64. 